MATEC Web of Conferences 47, 01005 (2016)

DOI: $10.1051 /$ matecconf/20164701005

(C) Owned by the authors, published by EDP Sciences, 2016

\title{
The Potential of Artificial Polyethylene Coarse Aggregate (APECA) on Compressive Strength of Concrete After Exposed by Temperatures
}

\author{
Shahrul Niza Mokhatar ${ }^{1, a}$, Josef Hadipramana ${ }^{1}$, Siti Nurhidayah Mohd Isa ${ }^{2}$ and Mohamed Muftah \\ Mustafa $^{2}$ \\ ${ }^{1}$ Jamilus Research Center, Universiti Tun Hussein Onn Malaysia, 86400 Parit Raja, Johor, Malaysia \\ ${ }^{2}$ Faculty of Civil and Environmental Engineering, Universiti Tun Hussein Onn Malaysia, 86400 Parit Raja,Johor, \\ Malaysia
}

\begin{abstract}
The strength contribution of Artificial Polyethylene Coarse Aggregate (APECA) as a coarse aggregate replacement in concrete are explored. The compression tests is carried out on twenty-one specimens of concrete cube with $0 \%, 3 \%, 6 \%$, and $9 \%$ of APECA by utilizing two stages: The concrete specimens containing $6 \%$ of APECA as coarse aggregate are heated at different temperatures, the strength of concrete mixes with $0 \%, 3 \%, 6 \%$ and $9 \%$ APECA were compared under normal condition (un-heated) and after exposed by $250^{\circ} \mathrm{C}$. Based on literatures, $6 \%$ of APECA had an optimal percentage that contribute to the compressive strength of concrete compared to $0 \%, 3 \%$, and $9 \%$ of APECA concrete. Thus, $6 \%$ ratio of APECA concrete was applied for continuous observation, which applied various temperatures at $150^{\circ} \mathrm{C}, 200^{\circ} \mathrm{C}$, and $250^{\circ} \mathrm{C}$. As results, it is observed that the $6 \%$ APECA concrete at $150^{\circ} \mathrm{C}$ had the highest compressive strength than other temperature $\left(200^{\circ} \mathrm{C}\right.$ and $\left.250^{\circ} \mathrm{C}\right)$. Also, it is found that the APECA concrete strength decrease as exposed by higher temperature. However, Scanning Electron Microscope (SEM) results reveals that the APECA melting in the concrete and filled the micro-crack of concrete. It can be concluded that, the APECA has the potential to be a coarse aggregate replacement and more detailed investigations are however demanded to modify the APECA in order to increase its physical properties.
\end{abstract}

\section{Introduction}

Nowadays, lightweight concrete still becomes most popular interest among researchers due to its special properties. Lightweight concrete can bring down the weight problem compared to ordinary concrete with $2400 \mathrm{~kg} / \mathrm{m}^{3}$ of density, which contributes to the weight penalty in large volume structures. Besides that, the global economic recession forced materials price increased, consequently the constructions would be high cost, including the cost for coarse aggregate [1]. Hence, to overcome this problem, the ordinary constituent material must be superseded by the low-cost material to cut the expense construction. This occasion provides a chance to waste materials to apply. Re-use waste plastic for replacing ordinary coarse aggregate concrete is the one ways to solve that problem. The waste plastic bag is a non-degradable material and it gives high impact to the environment due to

\footnotetext{
${ }^{a}$ Corresponding author : shahruln@uthm.edu.my
} 
people are abandoned the plastic waste. Based on this case, it is a severe trouble such that contributes to environmental pollution and wastage of natural resources [2]. In this study, an attempt has been made to re-use the plastic bag as an Artificial Polyethylene Coarse Aggregate (APECA) and replaced the ordinary (natural) coarse aggregate with APECA in the concrete to produce the lightweight concrete.

Fundamentally, the concrete is a high-temperature resistance, which it can conduct heat slowly and able to store a considerable amount of heat from the environment. Thus, a previous investigation [3] stated that the evaluation of fire temperature on the concrete strength was essential for rehabilitation, strengthening, or reconstruction of the structure. Therefore, this study presents the investigation of compressive strength of concrete containing APECA with the various percentage and exposed by different temperatures. APECA is lighter than the natural aggregate, therefore, the APECA concrete will produce lower density than ordinary concrete. The previous investigation $[2,4]$ observed that the APECA was made from the waste plastic bag and underwent the heating process about $150^{\circ} \mathrm{C}$ for 10 minutes as shown in Figure 2. The size of APECA based on the standard diameter size of ordinary aggregate by range from 14 to $20 \mathrm{~mm}$ in the ball shape. Figure 1 present the compression strength of specimens for each percentage of APECA for 7 and 28 days. It can be seen that the concrete mixes containing $6 \%$ APECA produces highest yet optimum strength about $10 \%$ from normal concrete. Meanwhile, concrete with $9 \%$ APECA will significantly reduce the strength of concrete about $60 \%$. It is may be due to the bond strength between artificial aggregate and cement paste.

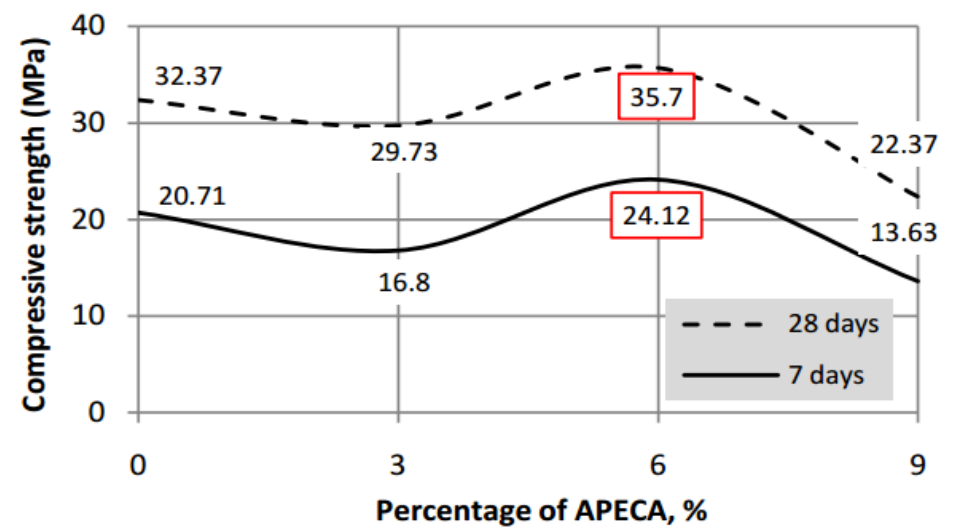

Figure 1. Compressive strength of different percentage of APECA in concrete mix [4].

Basically, the strength of concrete will be decreased when exposed in high temperature, especially on compressive strength. The high-temperature give effects on concrete strength, due to the dehydration of concrete. The dehydration will be occurred by driving out of a free water, interlayer water and chemically combined water [5]. The strength of concrete becomes a loss in the range of the temperature between $400^{\circ} \mathrm{C}$ and $800^{\circ} \mathrm{C}$. At temperature $400^{\circ} \mathrm{C}$, the compressive strength of specimens reduced gradually and at $800^{\circ} \mathrm{C}$, the concrete strength decreased about $80 \%$ [5].

\section{Materials and Methods}

\subsection{Concrete mix design}

Table 1 lists the ratio of constituent materials for normal concrete that recommended by Department of Environmental (DOE) to achieve $25 \mathrm{~N} / \mathrm{mm}^{2}$ of compressive strength on 28 days. In this investigation, the specimen was prepared based on the two stages. The first stage focus on the strength of concrete specimens containing $6 \%$ of APECA as coarse aggregate that heated at different 
temperatures. The second stage involve the strength comparisons of concrete mixes with $0 \%, 3 \%, 6 \%$ and $9 \%$ APECA under normal condition (un-heated) and after exposed by $250^{\circ} \mathrm{C}$. The volumes of concrete were determined to ensure the ratio between all the materials were suitable for grade 25 $\mathrm{N} / \mathrm{mm}^{2}$ [6]. This investigation produced totally twenty-one specimens of concrete cubes with $150 \mathrm{~mm}$ x $150 \mathrm{~mm}$ x 150 of size.

Table 1. Quantities of material based on DOE method.

\begin{tabular}{|c|c|c|c|c|c|c|}
\hline \multirow{2}{*}{ Quantities } & \multirow{2}{*}{ Cement } & \multirow{2}{*}{ Water } & \multirow{2}{*}{ Fine } & \multicolumn{3}{|c|}{ Coarse Aggregate (Kg) } \\
\hline & & & & $10(\mathrm{~mm})$ & $20(\mathrm{~mm})$ & $40(\mathrm{~mm})$ \\
\hline Per $\mathbf{m}^{3}$ (to nearest $5 \mathrm{Kg}$ ) & 340 & 190 & 710 & - & 1157 & - \\
\hline Per trial mix of $3.375 \times 10^{-3} \mathrm{~m}^{3}$ & 1.145 & 0.61 & 2.396 & - & 3.905 & - \\
\hline
\end{tabular}

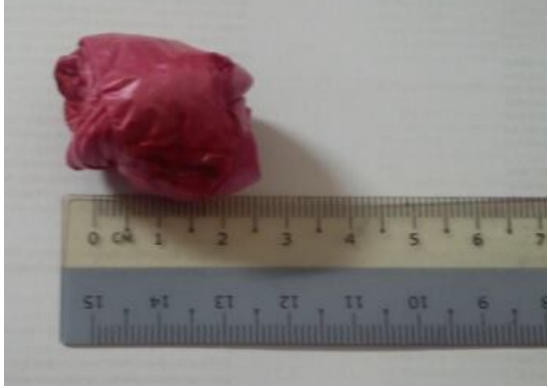

(a)

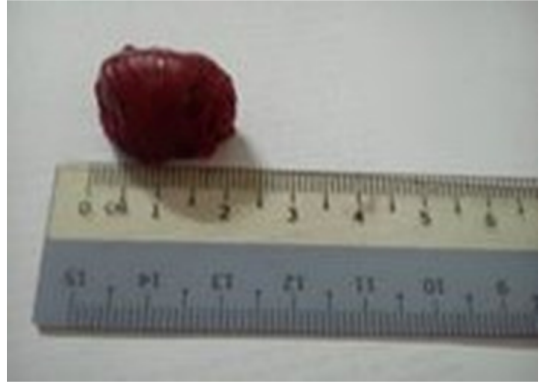

(b)

Figure 2. Condition of APECA (a) before and (b) after heating process.

\subsection{Compressive strength test}

Basically, the function of concrete is able to support and carry the compression load. This is an important parameter of the investigation was tuned by using the compressive test [6] on the cube concrete specimens. The compressive test was conducted on concrete with optimum percentage $(6 \%)$ at different temperature $\left(150^{\circ} \mathrm{C}, 200^{\circ} \mathrm{C}\right.$ and $\left.250^{\circ} \mathrm{C}\right)$. Further, the compressive strength of concrete cube containing $0 \%, 3 \%, 6 \%$ and $9 \%$ of APECA were investigated in normal condition (un-heating) and heated at $250^{\circ} \mathrm{C}$.

\subsection{Heating exposure technique}

Generally, the loss rate of concrete strength increased, when gravel concrete was exposed to a temperature of $250^{\circ} \mathrm{C}$ for more than 1 hour. This agrees with the previous investigation [7], that the reduction in bending strength of concrete was increased when the concrete heated. The bending strength of gravel concrete was extremely affected by heat exposure at $250^{\circ} \mathrm{C}$ for 2 hours and 3 hours for protected and unprotected specimens, respectively. Therefore, this study applied $250^{\circ} \mathrm{C}$ for 1 hour to heat the APECA concrete specimens before conduct the compressive test.

At 28 days, all specimens of concrete cubes were removed from the curing tank and were dried in $25-30^{\circ} \mathrm{C}$ room temperature. The first stage, $6 \%$ of APECA concrete were heated at $150^{\circ} \mathrm{C}, 200^{\circ} \mathrm{C}$, and $250^{\circ} \mathrm{C}$ in an oven for about 1 hour. Then, the concrete cube with different percentage of APECA were heated at $250^{\circ} \mathrm{C}$ for 1 hour as well. Before compression test, all specimens were cooling down in 30 minutes room temperature to ease the handling process on the concrete specimens. 


\subsection{Microstructure of APECA concrete}

To describe the microstructure of APECA concrete, Scanning Electron Microscopy (SEM) has been employed. Changes to the structure caused by the heat need to be investigated and analysed directly with visualization, predominantly, the changes of the microstructure of concrete and APECA due to the heat mechanism. Owing to heat, the matrix concrete would be depreciation and generated the micro-cracks, besides the APECA would be melted. By using SEM, the changes of structure could be analysed, because SEM can achieve better resolution in micrometer of scale. Before sample was analysed under SEM, the sample specimens coated by Platinum $(\mathrm{Pt})$ for 1 minute in sputter coater machine to avoid the bias or excess of reflected light.

\section{Results and Discussions}

\subsection{Compressive strength of 6\% APECA concrete exposed by different temperature}

As previously mentioned, in the literature review [4], the $6 \%$ of APECA used for an optimum percentage in APECA concrete. Therefore, this study implemented $6 \%$ of APECA concrete to determine the strength of concrete with different temperatures i.e. $150^{\circ} \mathrm{C}, 200^{\circ} \mathrm{C}$ and $250^{\circ} \mathrm{C}$.

Figure 3 presents a compressive strength of $6 \%$ APECA concrete with different temperature at $150^{\circ} \mathrm{C}, 200^{\circ} \mathrm{C}$ and $250^{\circ} \mathrm{C}$. In general, at $150^{\circ} \mathrm{C}$, the $6 \%$ of APECA concrete reached a highest compressive strength, which was $31.6 \mathrm{~N} / \mathrm{mm}^{2}$, while, the lowest compressive strength was 28.6 $\mathrm{N} / \mathrm{mm} 2$ at the $250^{\circ} \mathrm{C}$. It is conform to the works presented by Bastami et al. [5] that the higher temperature reduce the strength of concrete. It is interesting to see that the APECA concrete were also reduced its strength when the temperature increased. It is clearly explained by [8] that the high temperature generated the alteration of mechanical properties of concrete due to chemical/physical transformations of aggregate and paste by temperature. Further, the concrete is very risk when it is exposed by fire because concrete is not stable at high temperatures and the concrete can dehydrate $[9,10]$.

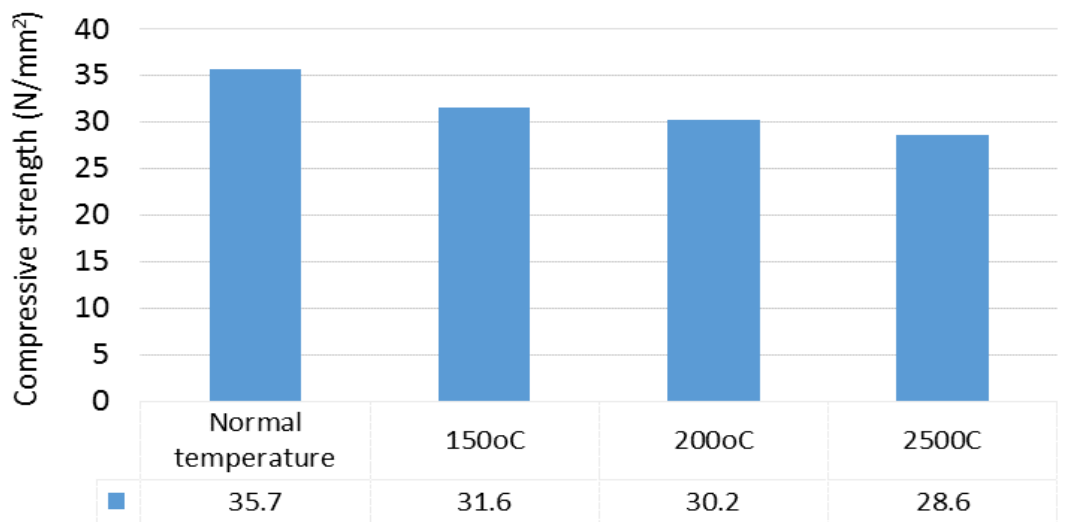

Figure 3. Compressive strength $6 \%$ of APECA with different temperature.

\subsection{Compression strength comparisons of different percentage of APECA at normal condition (un-heated) and after exposed by $250^{\circ} \mathrm{C}$}

Figure 4 illustrates the compressive strength of $0 \%, 3 \%, 6 \%$ and $9 \%$ of APECA concrete at two conditions; un-heated condition and after exposed by $250^{\circ} \mathrm{C}$. It is important to note that the better compressive strength possessed by APECA concrete with normal condition (un-heated) compared to another, which was exposed by heat at $250^{\circ} \mathrm{C}$. This can relates to dehydration process [7, 10]. 
Focusing and examining the concrete specimens under un-heated condition, the concrete with $6 \%$ APECA is the highest compressive strength. Based on comparison of all ratios under heating process, it is clearly shown that the $0 \%$ APECA is higher than all ratio. In addition, $6 \%$ of APECA concrete is higher than the other two ratio (3\% and $9 \%$ ). It is due to the poor bonding interaction between APECA surface and cement matrix even after exposed by temperature.

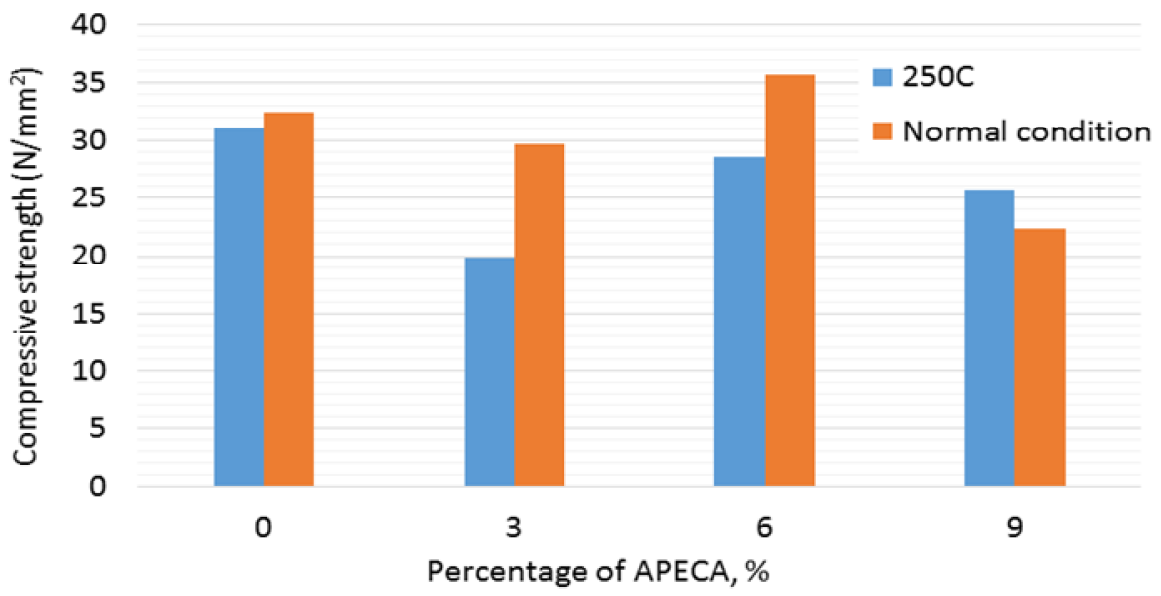

Figure 4. Comparisons of compressive strength of APECA concrete exposed at $250^{\circ} \mathrm{C}$ and in normal condition (un-heated)

\subsection{Microstructure of APECA concrete}

Figure 5 reveals the visual result of SEM for APECA concrete before and after being exposed by $250^{\circ} \mathrm{C}$ for 1 hour. Initially, before heated, the surface of APECA concrete produce micro-crack in cement matrix (refer Figure 5a).

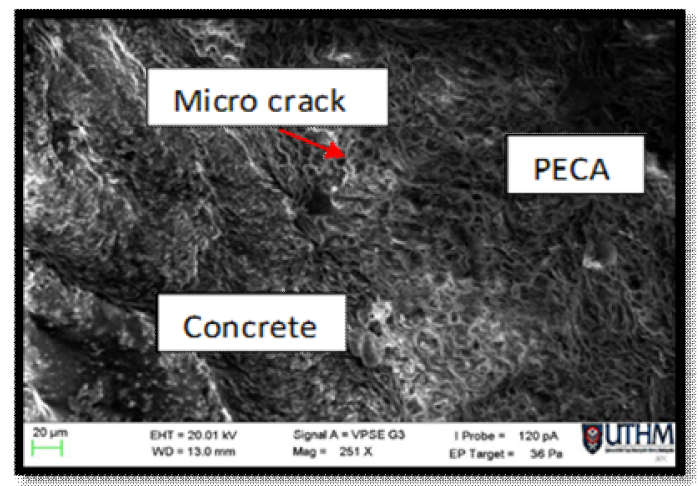

(a)

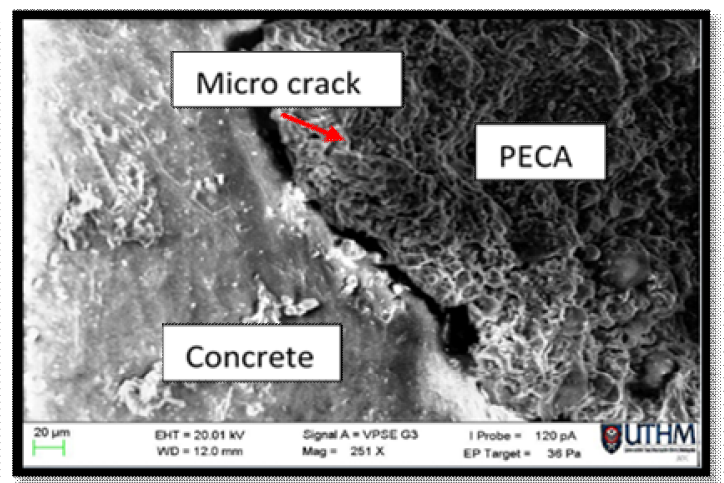

(b)

Figure 5. Microstructure of APECA Concrete before (a) and after (b) exposed to $250^{\circ} \mathrm{C}$ for 1 hour

While, after exposed to $250^{\circ} \mathrm{C}$, it can be seen that the APECA were melted and filled the microcrack as shown in Figure 5b. The second results contrary to Wasim Khaliq and Hammad Anis Khan [11] that found the development of micro-crack on concrete after exposed by high temperature in the range of $200^{\circ} \mathrm{C}$ to $600^{\circ} \mathrm{C}$. In general, the micro-crack size in concrete reduced after being heated with temperature due to the APECA melted at temperatures above $160^{\circ} \mathrm{C}[2,4]$. It is essential to state that the APECA covering almost the whole micro-crack in concrete. Other than that, the presence of 
APECA in concrete under heating delayed the dehydration of concrete. Yuan and Li [12] reported that the coated concrete considerably increased the carbonation resistance under elevated high temperatures. Meanwhile, some materials polymer can be used as a coating of concrete to reduce temperature effect [13].

\section{Conclusions}

The percentage of APECA plays a vital role in determining the compressive strength of concrete. In general, the result showed that the $6 \%$ of APECA concrete are able to produce highest compressive strength at $150^{\circ} \mathrm{C}$. Further, APECA covering almost the whole micro-crack in concrete when heated at elevated temperature. However, the results indicate that the APECA concrete reduced its strength when the temperature increased. Nevertheless, APECA has a potential to be a coarse aggregate replacement and more detailed investigations are however demanded to modify the physical properties of APECA in order to increase its capability as a coarse aggregate replacement.

\section{References}

[1] A.P. Adewuyi and T. Adegoke, Exploratory study of periwinkle shells as coarse aggregates in concrete works, J. of Engineering and Applied Sciences, 3(6), 1-5, (2008).

[2] M.M. Bakri A., C.M. Ruzaidi, M.N. Norazian, H. Kamarudin, S.M. Tarmizi and P. Besar, Effects of HDPE plastic waste aggregate on the properties of concrete, J. of Asian Scientific Research, 1(7), 340-345, (2000).

[3] B. Jonaitis and V. Papinigis, Effect of long-term loading and fire temperatures on mechanical properties of concrete, J. of Civil Engineering and Management, 11(4), 283-288, (2005).

[4] S.N. Mokhatar, Z.M. Jaini, M.K. Burhanudin, M.L. A. Jeni, and M.N.N Ismail, An experimental study of reinforced concrete beams with artificial aggregate concrete infill under impact loads, International Civil and Infrastructure Engineering Conference 2014, 691-701, (2014).

[5] M. Bastami, A. Chaboki-Khiabani, M. Baghbadrani, and M. Kordi, Performance of high strength concretes at elevated temperatures, Scientia Iranica, 18(5), 1028-1036, (2011)

[6] BS1881, Method for determination of compressive strength, Part 116, (1991)

[7] K. Sakr and E. El-Hakim, Effect of high temperature or fire on heavy weight concrete properties, Cement and Concrete Research, 35(3), 590-596, (2005).

[8] H. Mohamed, M.N. Ismail and N.S. Ibrahim, Physico-mechanical, microstructure characteristics and fire resistance of cement pastes containing $\mathrm{Al}_{2} \mathrm{O}_{3}$ nano-particles, Construction and Building Materials, 91, 232-242, (2015).

[9] M. Heikal, Effect of temperature on the physico-mechanical and mineralogical properties of Homra pozzolanic cement pastes, Cement and Concrete Research, 30, 1835 - 1839, (2000).

[10] C. Alonso and L. Fernandez, Dehydration and rehydration processes of cement paste exposed to high temperature environments, J. of Materials Science, 39, 3015 - 3024, (2004).

[11] W. Khaliq and H.A. Khan, High temperature material properties of calcium aluminate cement concrete, Construction and Building Materials, 94, 475-487, (2015).

[12] G. Yuan and Q. Li, The use of surface coating in enhancing the mechanical properties and durability of concrete exposed to elevated temperature, Construction and Building Materials, 95, 375-383, (2015).

[13] A.A. Almusallam, F.M. Khan, S.U. Dulaijan, and O.S.B. Al-Amoudi, Effectiveness of surface coatings in improving concrete durability, Cement and Concrete Composites, 25(4-5), 473-481, (2003). 